\title{
An Empirical Study on Coordination Degree Between Land Urbanization and Population Urbanization in Qinghai Province Based on High-quality Development
}

\author{
Pan Zhihong ${ }^{1,}$, Xiang Wenling ${ }^{2,}$, Ding Shengxi ${ }^{3 *}$
}

\begin{abstract}
${ }^{1}$ Qinghai university school of finance and economics 1
${ }^{2}$ Qinghai university school of finance and economics 2

${ }^{3}$ Qinghai university school of finance and economics 3

*Corresponding author. Email:qhdxjixdsx@126.com
\end{abstract}

\begin{abstract}
It is an important strategy to realize the coordinated development of land urbanization and population urbanization in Qinghai Province. Based on the analysis of the coordinated development of land urbanization and population urbanization in Qinghai Province and two cities in the province, this paper determines the evaluation index system from the evaluation level of population and land by building a model and using entropy method, and reveals that land urbanization in Qinghai Province lags behind population urbanization, and it is urgent to realize the coordinated development of the two.
\end{abstract}

Keywords: land urbanization, population urbanization, coordination degree, entropy method

\section{PREFACE}

Under the strategic background that urbanization development will shift to scale expansion and quality improvement, the situation that population urbanization lags behind land urbanization is particularly prominent. ${ }^{[1]}$ In this regard, the government comprehensively implements the rural revitalization strategy, promotes regional coordinated development and new urbanization at a higher level, and builds a highquality development of land spatial layout and support system. ${ }^{[2]}$ Qinghai Province is also in a critical period of accelerating the development of new urbanization. ${ }^{[3]}$ Its economic development has an important impact on the whole western region. ${ }^{[4]}$

\section{BASIC SURVEY OF LAND URBANIZATION AND POPULATION URBANIZATION IN QINGHAI PROVINCE}

\subsection{The status quo of population urbanization and land urbanization in Qinghai province}

\subsection{1 population urbanization in Qinghai province}

In recent years, the urbanization level of Qinghai Province has gradually improved, and the urbanization pattern has basically taken shape. By the end of 2019, the province's resident population had been rising continuously, increasing by 45,900 compared with the previous year, of which the urban population accounted for $55.55 \%$ and the minority population accounted for $47.71 \%$. According to the statistical yearbook of Qinghai Province, 1949-1955 was the initial stage of urbanization, and the urbanization rate at the end of the stage was $7 \%$; From 1956 to 1977 , it was an unconventional development stage of urbanization, the urbanization rate increased by $108.57 \%$. From 1978 to 2000 , it was a rapid development stage of urbanization, and the urbanization rate increased by $138.15 \%$. 2000-2019 is the accelerated development stage of urbanization, and the urbanization 
rate growth rate is $59.62 \%$. Since the implementation of the western development strategy in Qinghai Province, the population industrial structure has been continuously optimized. From 2000 to 2019, the number of employees in the primary industry in Qinghai Province generally showed a downward trend, while the number of employees in the secondary and tertiary industries increased dynamically year by year. In 2019, the regional GDP of the whole province increased by $1.5 \%$ over the previous year. The proportion of industrial employment structure changed from 44.3: 20.6: 35.1 in 2007 to 52.7: 33.67: 77.23 in 2019. According to the S-curve theory, the urbanization level of Qinghai Province is generally in the middle stage of urbanization.

\subsection{2 land urbanization in Qinghai province}

The utilization and distribution of urban land resources in Qinghai Province is unbalanced internally, and the scale distribution of urban land is unbalanced, which is manifested by the great difference in construction between cities, prefectures and built-up areas. The unreasonable land use structure is mainly manifested in the low green coverage rate of built-up areas in Qinghai Province and the imbalance of per capita urban road area. From 2016 to 2019, the green coverage rate of built-up areas in Qinghai Province is generally rising, but the rising speed is slow.

\subsection{Land Urbanization and Population Urbanization in Qinghai Province}

\subsection{1 distribution of urban areas}

Due to the differences in the natural geographical environment, natural resource endowments and economic and social development in different regions of the province, the urbanization level of different regions is quite different, and the difference in the number and distribution of urban population is significant. From the perspective of urban area layout, as of 2019, there are 2 cities above prefecture level and 4 county-level cities in the province, with a total of 406 townships. Xining City, Haidong City and Haixi Prefecture accounted for more than half of the total number of townships in the province.

\subsection{2 urban population distribution}

By 2019, the urban population of Qinghai Province increased by $0.76 \%$ compared with the previous year, among which Xining increased by $15.11 \%$, Haidong increased by 13,000 , Haixi increased by $0.4 \%$, Hainan increased by 0.17 million, Haibei increased by 0.06 million, Huangnan increased by $1.23 \%$, and Yushu increased by 0.59 million Among them, the urban population of Xining City, Haidong Prefecture and Haixi Prefecture accounted for $80.8 \%$ of the province's urban population. [5]It can be seen from Figure 3.6 that since
2000, the urbanization level of Qinghai Province has steadily increased, the proportion of built-up areas has increased year by year, and the green coverage rate of built-up areas has been continuously improved. Under the influence of the policy of withdrawing land and setting up a city in Haidong City in 2013, except Xining and Haixi, the built-up area first exceeded 45 square kilometers in other cities.

\section{AN EMPIRICAL ANALYSIS OF THE COORDINATION DEGREE BETWEEN LAND URBANIZATION AND POPULATION URBANIZATION IN QINGHAI PROVINCE}

\subsection{Build an evaluation index system}

There are 2 target layers and 15 index layers in this index system, as shown in Table 1:

Table 1.Index System

\begin{tabular}{|c|c|c|c|}
\hline Target layer & $\begin{array}{c}\text { Factor evaluation } \\
\text { layer }\end{array}$ & Index layer & weight \\
\hline \multirow{6}{*}{$\begin{array}{l}\text { Population } \\
\text { urbanization }\end{array}$} & $\begin{array}{l}\text { industrial } \\
\text { structure }\end{array}$ & $\begin{array}{l}\text { Proportion of } \\
\text { secondary and } \\
\text { tertiary } \\
\text { production to } \\
\text { GDP }\end{array}$ & P1 \\
\hline & $\begin{array}{l}\text { population } \\
\text { structure }\end{array}$ & $\begin{array}{c}\text { Proportion of } \\
\text { urban population }\end{array}$ & P2 \\
\hline & \multirow{2}{*}{$\begin{array}{l}\text { Employment } \\
\text { situation of } \\
\text { workers }\end{array}$} & $\begin{array}{l}\text { Proportion of } \\
\text { employed } \\
\text { population in } \\
\text { secondary and } \\
\text { tertiary industries }\end{array}$ & P3 \\
\hline & & $\begin{array}{l}\text { registered urban } \\
\text { unemployment } \\
\text { rate }\end{array}$ & P4 \\
\hline & \multirow[t]{2}{*}{$\begin{array}{l}\text { population } \\
\text { quality }\end{array}$} & $\begin{array}{l}\text { Number of } \\
\text { college students } \\
\text { per } 10,000 \\
\text { people }\end{array}$ & P5 \\
\hline & & $\begin{array}{l}\text { Engel coefficient } \\
\text { of urban } \\
\text { residents }\end{array}$ & P6 \\
\hline \multirow{5}{*}{$\begin{array}{l}\text { Land } \\
\text { urbanization }\end{array}$} & \multirow{4}{*}{ quality of life } & $\begin{array}{l}\text { urban per capita } \\
\text { disposable } \\
\text { income }\end{array}$ & P7 \\
\hline & & $\begin{array}{l}\text { Number of health } \\
\text { technicians per } \\
\text { ten thousand } \\
\text { people }\end{array}$ & P8 \\
\hline & & $\begin{array}{l}\text { Total retail sales } \\
\text { of urban social } \\
\text { consumer goods } \\
\text { Built-up area }\end{array}$ & P9 \\
\hline & & Built-up area & L1 \\
\hline & Land scale & $\begin{array}{l}\text { Per capita park } \\
\text { green area }\end{array}$ & L2 \\
\hline
\end{tabular}




\begin{tabular}{ccc}
\hline Land use & $\begin{array}{c}\text { Green coverage } \\
\text { rate of built-up } \\
\text { area }\end{array}$ & L3 \\
Ltructure & $\begin{array}{c}\text { Urban road area } \\
\text { per capita }\end{array}$ & L4 \\
Land input level & $\begin{array}{l}\text { Average local } \\
\text { financial input } \\
\text { Land output level }\end{array}$ & L5 \\
fiscal revenue local & L6 \\
\hline
\end{tabular}

\subsection{Overall Evaluation of Coordinated} Development of Land Urbanization and Population Urbanization in Qinghai Province

There are mainly the following steps:

(1)Standardized data processing: Because the actual index values are different in dimensions, in order to eliminate the influence of different dimensions on the evaluation results, it is necessary to standardize each index data.

(2) Determine the information entropy value:

$$
e_{j}=-k \sum_{i=1}^{m} P_{i j \ln P_{i j}}
$$

(3)Calculate the weight of each index

$$
P_{J}=\frac{d_{j}}{\sum_{j=1}^{m} d_{j}}
$$

(4)Calculation of land urbanization index and population urbanization index.

$$
\begin{aligned}
& P(a)=\sum_{i=1}^{m} P_{i} X_{i^{\prime}} \\
& L(b)=\sum_{i=1}^{m} L_{i} Y_{i^{\prime}}^{\prime}
\end{aligned}
$$

(5)Calculate the degree of development and coordination

$$
\mathrm{T}=\alpha \mathrm{P}(a)+\beta \mathrm{L}(b)
$$

(6)Calculate the degree of coordinated development

\subsection{Main conclusions}

Through the above calculation steps, taking Qinghai Province as an example, the specific results are shown in Figure 1:

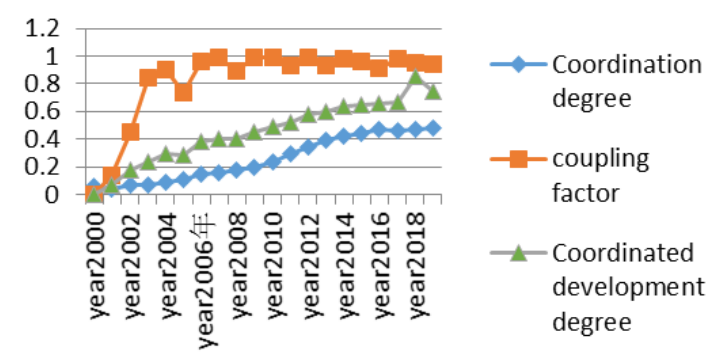

Figure 1 Change curve of Qinghai Province from 2000 to 2019

As shown in the figure, from 2000 to 2019, the values of $\mathrm{L}(\mathrm{b})$ and $\mathrm{P}(\mathrm{a})$ in Qinghai Province showed a dynamic upward trend, and the coordinated development degree of land urbanization and population urbanization in this period also gradually increased. Among them, from 2000 to 2012, the coordinated development level of population urbanization and land urbanization was very low, which was in a state of imbalance (2000-2005) and transition (2006-2012). During this period, the land urbanization index was lower than the population urbanization index, and the development degree $\mathrm{T}$ was always below 0.4 (0.06-0.34). The overall development level of urbanization in Qinghai Province was in a backward stage and coordinated development since 2013, the coordinated development level of population urbanization and land urbanization has been greatly improved, from 0.00 in 2000 to 0.69 in 2019. Across the coordination interval, the subtype of coordinated development belongs to the primary coordinated development category.

To sum up, through determining the evaluation index system of urbanization coordination in Qinghai Province from 2000 to 2019, the empirical analysis shows that both $\mathrm{L}(\mathrm{b})$ and $\mathrm{P}(\mathrm{a})$ in Qinghai Province are in a dynamic upward trend from 2000 to 2019, and the coordinated development degree $\mathrm{D}$ of population urbanization and land urbanization is steadily increasing. Among them, the degree of coordinated development in 2000-2005 was very low, which was in disorder (2000-2005) and transitional state (2006-2012), which was due to the fact that $\mathrm{L}(\mathrm{b})$ was obviously lower than $\mathrm{P}(\mathrm{a})$ and $\mathrm{T}$ was always below 0.4 (0.06-0.34), which further led to the low level of coordinated development Since 2015, the coordinated development level of population urbanization and land urbanization has been improved from 0.00 in 2000 to 0.69 in 2019.

\section{CONCLUSION}

There are regional spatial differences in the level of urban development in Qinghai Province, the government can adjust the industrial structure, make the industrial structure progress towards the two goals of rationalization and upgrading, and give prominence to the development of modern service industry. Secondly, it is necessary to highlight the characteristics of cities, strengthen the leading role of central cities in regional economy, and 
strengthen the leading role of central cities in regional economy, so as to drive the development of other cities in the radiation area.

\section{AUTHORS' CONTRIBUTIONS}

In recent years, scholars at home and abroad have put forward different opinions on urbanization, but there are few researches on urbanization development in Qinghai Province, especially on the coordinated development of land urbanization and population urbanization, and the suggestions put forward are not concrete enough. Therefore, this paper quantitatively calculates the coordinated development degree of land urbanization and population urbanization in Qinghai Province from 2000 to 2019 , and determines the development stage of land urbanization and population urbanization in the whole region of Qinghai Province; On the basis of empirical research using entropy method, the degree of each factor affecting the coordinated development of land urbanization and population urbanization is determined, and corresponding policy suggestions can be put forward.

\section{ACKNOWLEDGMENTS}

After writing, I sincerely thank Mr. Ding Shengxi for her guidance, her careful attitude is worth learning, I will do not forget your initiative mind, keep working hard and constantly improve myself.

\section{FUND PROJECT}

National Social Science Fund Project "Research on Dynamic Mechanism and Path Selection of Green Development in Qaidam Basin" (19BMZ154).

\section{REFERENCES}

[1] Chen C., He H., (2017) Research on the Coordination Measurement of Population Urbanization and Land Urbanization in Gansu Province. Journal of Lanzhou University of Finance and Economics., 3:87-93.

[2] Ma M.,(2020) Communique of the Fifth Plenary Session of the 19th Central Committee of the Communist Party of China. In: Fifth Plenary Session of the 19 th Central Committee of the Communist Party of China., Beijing. pp1-2.

[3] Ding S., Yin S K., Wang J, QU B., Sun L X. (2015) Research on Regional Economic Theory and Qinghai Regional Economic Development. China Economic Press, Beijing.

[4] Hao L J , (2016) Research on the Coordinated Development of Urbanization and County Economy in Qinghai Province. Qinghai Normal University.
[5] Qinghai Provincial Bureau of Statistics, Qinghai Provincial Statistical Yearbook, (2000-2019) China Statistics Press,Beijing. 